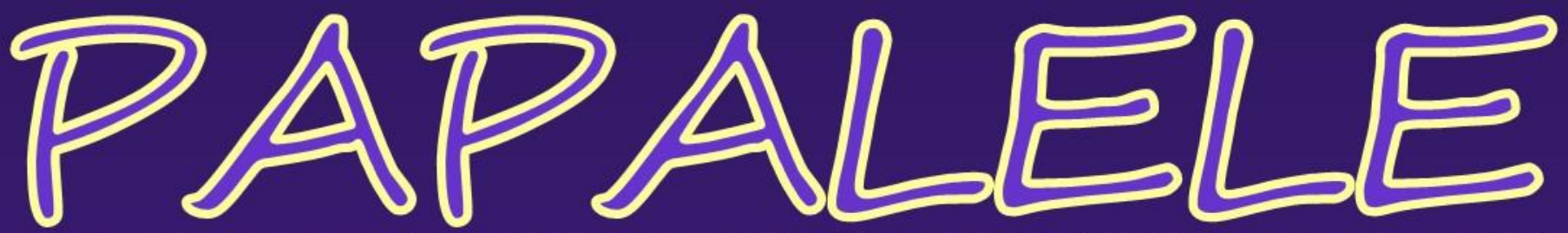
JURNAL PENELITIAN SOSIAL EKONOMI PERIKANAN DAN KELAUTAN

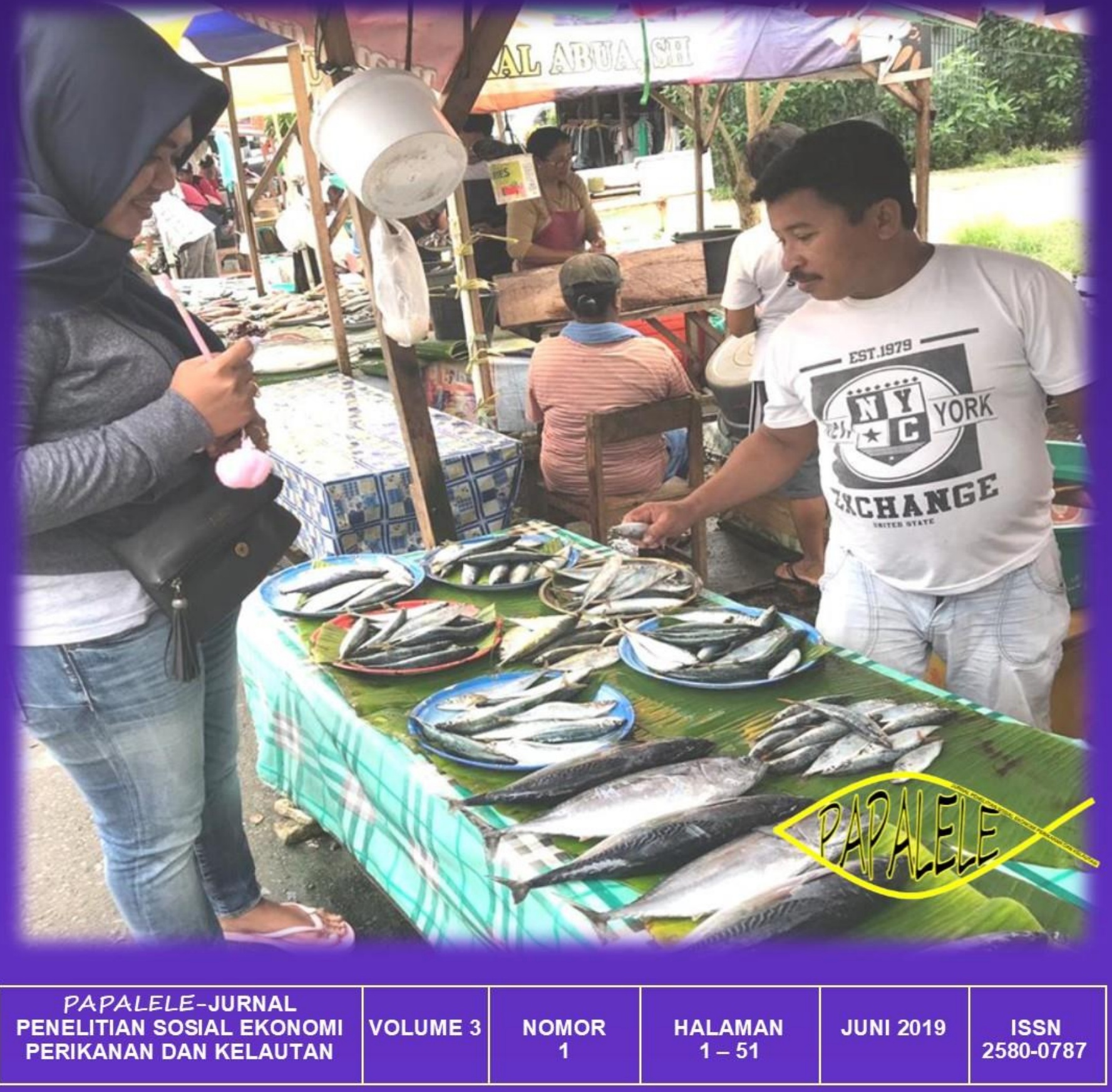

Diterbitkan oleh:

(2) PROGRAM STUDI AGRIBISNIS PERIKANAN

mings FAKULTAS PERIKANAN DAN ILMU KELAUTAN 


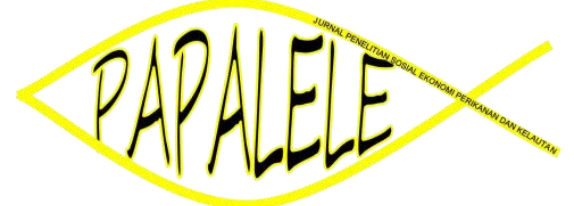

\section{JURNAL \\ PENELITIAN SOSIAL EKONOMI PERIKANAN DAN KELAUTAN}

\author{
PENANGGUNG JAWAB \\ Ketua Program Studi Sosial Ekonomi Perikanan \\ KETUA DEWAN REDAKSI \\ D. Bawole
}

RADAKTUR AHLI

V. Nikijuluw, M.S. Baskoro, J. Hiariej, F. Rieuwpassa, P. Wenno

REDAKTUR PELAKSANA

St. M. Siahainenia, R.L. Papilaya, Y. Lopulalan, Y.M.T.N. Apituley, V.J. Pical, W. Talakua, E. Talakua

PELAKSANA TATA USAHA

L.M. Soukotta, A. Ruban, K. Pattimukay, J. Sangaji, F. de Lima

PENERBIT

Program Studi Sosial Ekonomi Perikanan Jurusan Agrobisnis Perikanan

Fakultas Perikanan dan Ilmu Kelautan Universitas Pattimura

\section{ALAMAT REDAKTUR}

Program Studi Sosial Ekonomi Perikanan Jurusan Agrobisnis Perikanan Fakultas Perikanan dan Ilmu Kelautan Universitas Pattimura

Jln. Mr. Chr. Soplanit Poka-Ambon Telp. (0911) 379859. Fax 379196

PAPALELE merupakan jurnal penelitian ilmu sosial ekonomi perikanan dan kelautan yang menyajikan artikel tentang hasil penelitian yang berkaitan dengan bidang sosial ekonomi perikanan dan kelautan. Setiap naskah yang dikirim akan dinilai secara kritis oleh tim penilai yang relevan sebelum diterbitkan. Jurnal ini diterbitkan dua kali setahun, bulan Juni dan Desember. 


\section{KATA PENGANTAR}

Puji dan syukur kami panjatkan kepada Tuhan Yang Maha Esa atas rahmat-Nya. Jurnal PAPALELE, Jurnal penelitian Sosial Ekonomi Perikanan dan Kelautan kembali diterbitkan.

PAPALELE, Jurnal penelitian Sosial Ekonomi Perikanan dan Kelautan sesuai dengan Keputusan Lembaga Ilmu Pengetahuan Indonesia Nomor 0005.25800787/JI.3.1.SK.ISSN/2017.0529 Mei 2017 telah mengeluarkan nomor ISSN 2580-0787 untuk mulai penerbitan edisi volume 1 nomor 1, Juni 2017, dan sekarang melanjutkan perebitan untuk edisi volume 3 nomor 1, Juni 2019. Pada edisi ini, sama seperti edisi sebelumnya ditampilkan lima tulisan penelitian yang berkaitan dengan ilmu sosial ekonomi perikanan dan kelautan.

Dengan diterbitkannya jurnal ini, diharapkan dapat memberikan informasi ilmiah di bidang sosial ekonomi perikanan dan kelautan kepada pembaca. Saran dan masukan dari pembaca sangat diharapkan guna kesempurnaan penerbitan jurnal di waktu depan.

$\underline{\text { REDAKSI }}$ 


\section{DAFTAR ISI}

Halaman

KATA PENGANTAR

DAFTAR ISI ii

EFISIENSI TEKNIS DAN EKONOMI PERIKANAN TUNA HAND LINE DI NEGERI TIAL KABUPATEN MALUKU TENGAH

Oleh: Priscyllia Franetha Siahainenia, Dionisius Bawole, dan Willem Talakua $1-10$

ANALISIS KELAYAKAN USAHA KERAMBA JARING APUNG (KJA) DENGAN SISTEM MONOKULTUR DAN POLIKULTUR DI TANJUNG MARTHAFONS KOTA AMBON

Oleh: Tiffany Evangeline Leatemia

KELAYAKAN USAHA POLE AND LINE DI NEGERI HATIVE KECIL KOTA AMBON

Oleh: Ferdinan W. M. Haulussy

PRODUKTIVITAS DAN RESIKO USAHA PERIKANAN PURSE SEINE

DI NEGERI LATUHALAT

Oleh: Robert Frento Pattipeilohy dan Eygner Gerald Talakua

EFISIENSI DAN KEBERLANJUTAN USAHA PURSE SEINE DI KABUPATEN MALUKU TENGAH DAN KOTA AMBON

Oleh: Margie Wattimury 


\title{
EFISIENSI DAN KEBERLANJUTAN USAHA PURSE SEINE DI KABUPATEN MALUKU TENGAH DAN KOTA AMBON
}

\section{EFFICIENCY AND SUSTAINABILITY OF PURSE SEINE BUSINESS IN CENTRAL MALUKU DISTRICT AND AMBON CITY}

\author{
Margie Wattimury* \\ Program Studi Agrobisnis Perikanan, \\ Fakultas Perikanan dan Ilmu Kelautan, Universitas Pattimura \\ *) Penulis korespondensi: margiewattimury@gmail.com \\ Diterima 5 September 2019, disetujui 7 Oktober 2019
}

\begin{abstract}
ABSTRAK
Tingkat pendapatan usaha penangkapan ikan dengan purse seine ditentukan oleh efisiensi alokasi sumber daya ke dalam alternatif kegiatan perikanan tangkap. Jika sumber daya tidak digunakan secara efisien, maka terdapat potensi yang belum tereksploitasi untuk peningkatan pendapatan dan penciptaan surplus. Sebaliknya, jika sumberdaya dialokasikan secara efisien, maka tambahan sektor perikanan tangkap dapat diperoleh melalui usaha pengembangan berorientasi pertumbuhan. Oleh karena itu, diperlukan identifikasi efisiensi penggunaan sumbe rdaya untuk menentukan eksistensi perikanan tangkap purse seine. Hasil penelitian menunjukan bahwa estimasi efisiensi teknis penangkapan dengan analisi SPF (Stochastic Production Frontier) hasil tangkapan untuk perikanan purse seine di Kabupaten Maluku Tengah dan Kota Ambon dipengaruhi oleh panjang dan lebar alat tangkap, jumlah nelayan, nilai investasi dan waktu operasi penangkapan. Nilai efisiensi teknis penangkapan untuk nilai minimum adalah sebesar 0,10 dan untuk nilai maksimum adalah sebesar 0,99 dengan nilai rata-rata sebesar 0,48. Faktor-faktor yang mempengaruhi inefisiensi teknis penangkapan adalah pengalaman nahkoda dan tingkat pendidikan SMU nelayan. Untuk keberlanjutan usaha perikanan purse seine di Kabupaten Maluku Tengah dan Kota Ambon layak untuk dikembangkan. Dengan rata-rata nilai NPV sebesar Rp. 30.514.684.-/tahun, IRR sebesar 23,97\%, nilai B/C ratio sebesar 5,85. Rata-rata jangka waktu pengembalian modal investasi (PP) berdasarkan hasil analisis adalah sebesar 2,16 tahun, dengan BEP harga sebesar Rp. 6.606,- dan BEP produksi sebesar Rp. 3.765,-. Prioritas uatam strategi kebijakan pengembangan perikanan purse seine di Kabupaten Maluku Tengah dan Kota Ambon adalah pengembangan pendampingan pada kelompok nelayan, pengembangan teknologi tepat guna untuk penanganan hasil tangkapan, peningkatan produksi perikanan, dan pengembangan infrastruktur.
\end{abstract}

Kata kunci: efisiensi, keberlanjutan usaha, perikanan purse seine

\begin{abstract}
The level of purse seine business income is determined by the efficient allocation of resources for alternative capture fisheries activities. If resources are not used efficiently, there will be unexploited potential to increase income and create surpluses. Conversely, if resources are allocated efficiently, additional capture fisheries can be obtained through growth-oriented development efforts. Therefore, it is important to identify the efficient use of resources to determine the existence of purse seine fisheries. The results show that the estimated technical efficiency of the catch with SPF (Stochastic Production Frontier) analysis for purse seine fisheries in Central Maluku Regency and Ambon was influenced by the length and width of fishing gear, number of fishermen, amount of investment value and time of capture operations. The minimum value of catch technical efficiency is 0.10 and the maximum is 0.99 with an average 0.48. Factors influencing the technical inefficiency of fishing are the experience of captain and the education level of fishermen. Purse seine fishery business in Central Maluku Regency and Ambon City is feasible to be developed, showing by NPV value Rp. 30,514,684 / year, IRR 23.97\% and B / C ratio 5.85. The average return on investment (PP) based on the analysis is 2.16 years, with BEP price Rp. 6,606 and BEP production 3,765 kgs. The main priorities of purse seine fisheries development policy strategy in Central Maluku Regency and Ambon are the development of assistance to fishing groups, the development of appropriate technology to handle catches, increase fisheries production, and infrastructures development.
\end{abstract}

Keywords: efficiency, business sustainability, purse seine fisheries. 


\section{PENDAHULUAN}

Maluku merupakan Provinsi Kepulauan dengan luas sebesar 712.479,69 km² terdiri dari luas laut sebesar $658.294,69 \mathrm{~km}^{2}$ dan luas daratan sebesar $54.158 \mathrm{~km}^{2}$. Penduduknya sebagian besar bertempat tinggal ditepi pantai atau pesisir dengan mata pencaharian sebagai petani dan nelayan. Kondisi ini berarti potensi sumberdaya hayati dan keanekaragamannya cukup besar bagi pembangunan masyarakat Maluku.

Salah satu kawasan perairan Provinsi Maluku yang penting dan perlu mendapat perhatian adalah WPP Laut Banda, yang dikenal saat ini sebagai "WPP - 714 Laut Banda" (Nurkahim, et al., 2007). WPP - 714 Laut Banda mencakup hamper seluruh wilayah perairan Kabupaten Maluku Tengah termasuk Kota Ambon. Kawasan WPP tersebut diestimasi mengandung potensi sumberdaya ikan sebesar 278.400 ton/tahun, yang terutama didominasi oleh kelompok sumberdaya ikan pelagis kecil dan besar. Namun, potensi sumberdaya ikan tersebut telah memperlihatkan gejala "Overexploited" seperti ditujukan oleh ikan pelagis kecil (DKP RI, 2006). Kondisi tersebut mengindikasikan ketidakseimbangan antara input (kapal dan alat tangkap) dengan potensi sumberdaya sehingga mempengaruhi produktivitas penangkapan.

Menurut hasil kajian Nurhakim, et al (2007), sumberdaya ikan pelagis kecil yang cukup penting di WPP - 714 Laut Banda adalah ikan laying, teri, dan lemuru. Potensi ikan pelagis kecil tersebut terutama dimanfaatkan oleh para nelayan yang berbasis d Kabupaten Maluku Tengah dan Kota Ambon. Kedua wilayah Kabupaten/Kota ini merupakan pusatpusat kegiatan perikanan tangkap khususnya perikanan pelagis kecil, yang sangat berkembang di Maluku. Salah satu alat tangkap utama yang digunakan adalah "Purse Seine (Pukat Cincn)".

Pengelolaan usaha penangkapan purse seine tidak lepas dari pertimbangan yang bersifat teknis maupun ekonomis. Dengan demikian usaha penangkapan dapat diketahui efisiensi secara pasti, dengan melihat pengaruhnya dari proses produksi. Konsep efisiensi teknis merupakan konsep rasio input output suatu proses produksi baik dalam satuan fisik, nilai atau kombinasi keduanya, tanpa secara khusus memperhatikan keuntungan maksimum. Terhadap nilai ini yang penting adalah memaksimalkan produksi dengan menggunakan sejumlah input tertentu dan jika ini tercapai secara teknis proses produksi telah efisien.

Kemampuan sub sektor perikanan tangkap purse seine dalam memberikan kontribusi langsung terhadap kesejahteraan nelayan dan pertumbuhan ekonomi di Kabupaten Maluku Tengah dan Kota Ambon adalah sangat tergantung pada tingkat pendapatan usaha dan surplus yang dihasilkan oleh sub - sektor perikanan tangkap. Tingkat pendapatn dari usaha penengkapan menentukan kesejahteraan nelayan dan berperan penting dalam mengkondisikan pertumbuhan ekonomi.

Tingkat pendapatan usaha ditentukan oleh efisiensi alokasi sumberdaya ke dalam alternatif kegiatan perikanan tangkap. Efisiensi alokasi memberi makna, jika sumberdaya tidak digunakan secara efisien, maka terdapat potensi yang belum tereksploitasi untuk peningkatan pendapatan dan penciptaan surplus. Sebaliknya, jika sumberdaya dialokasikan secara efisien, maka tambahan sub - sektor perikanan tangkap dapat diperoleh melalui usaha pengembangan berorientasi pertumbuhan. Oleh karena itu, diperlukan identifikasi efisiensi penggunaan sumberdaya untuk menentukan eksistensi berbagai peluang pada perikanan tangkap khususnya untuk perikanan purse seine.

Fungsi produksi diartikan dengan hubungan fisik antara jumlah input yang dikorbankan dengan jumlah maksimum output yang dihasilkan. Hubungan fungsi produksi dalam perikanan tangkap (purse seine) dinyatakan sebagai fungsi dari vektor input (karakteristik kapal/purse seine), vektor input variabel (hari melaut, nelayan, BBM), input stok tak terkontrol (stok biomassa), dan vektor eksternal yang tak terkontrol seperti kondisi cuaca (Kirkley et al,. 2004).

Proses produksi dalam perikanan tangkap purse seine merupakan interkasi dari sifat sumberdaya dengan fakor internal penangkapan yang dapat dikendalikan, maupun faktor eksternal dalam penangkapan. Faktor eksternal berhubungan dengan kondisi perairan seperti gelombang, arus, dan angin. Perpaduan kedua faktor tersebut menimbulkan 
ketidakpastian bagi nelayan untuk menentukan secara pasti beberapa jumlah produksi maksimum yang dapat dicapai dalam proses penangkapan.

Eksploitasi sumberdaya ikan yang tidak terkendali menimbulkan kondisi ketidakseimbangan antara fishing input dan potensi sumberdaya ikan. Dampak ketidakseimbangan antara lain : kelebihan kapasitas, inefisiensi penangkapan, degradasi stok sumberdaya, dan penurunan CPUE. Dengan demikian, faktor efisiensi, keseimbangan input - output dan sumberdaya merupakan hal penting untuk dipertimbangkan dalam pengelolaan perikanan ketika timbul gejala penurunan produksi dan overfishing. Tantangan untuk memperthankan ketersediaan produksi sumberdaya ikan secara berkelanjutan adalah sangat kompleks, ditinjau dari sisi pemanfaatan dan kelestarian sumberdaya ikan.

Berdasarkan uraian di atas, maka yang menjadi ketertarikan bagi penulis untuk melakukan penelitian adalah melihat "Efisiensi dan Keberlanjutan Perikanan Purse Seine di Kabupaten Maluku Tengah". Adapun tujuan dari penelitian ini adalah: (1). Mengidentifkasikan faktor - faktor apa saja yang mempengaruhi produksi perikanan purse seine di Kabupaten Maluku Tengah dan Kota Ambon. (2). Menganalisis efisiensi dan keberlanjutan perikanan purse seine di Kabupaten Maluku Tengah dan Kota Ambon. (3). Meremuskan strategi kebijakan perikanan purse seine di Kabupaten Maluku Tengah dan Kota Ambon.

\section{METODE PENELITIAN}

\section{Metode yang digunakan dalam penelitian ini adalah metode survei. Penelusuran kepustakaan dilakukan dengan mengambil kasus di Kabupaten Maluku Tengah dan Kota Ambon.Survei yang digunakan dengan mengambil sampel dari suatu populasi atau melalui wawancara secara langsung dengan menggunakan kusioner sebagai alat pengumpul data pokok (Singaribun dan Effendi, 2008).}

\section{Metode Pengumpulan Data}

Dalam penelitian ini data yang dikumpulkan berupa data primer dan data sekunder.

\section{Data Primer}

Data primer diperoleh secara langsung dari reponden dan atau informan yang lain, dengan menggunakan daftar pertanyaan (kosioner) melalui wawancara langsung.

2. Data Sekunder

Data sekunder diperoleh melalui penelusuran dan penalaah studi-studi dokumen yang berhubungan dengan masalah-masalah yang diteliti. Data sekunder yang dikumpulkan antara lain meliputi gambaran umum mengenai daerah penelitian, keadaan geografis dan kependudukan.

\section{Metode Pengembilan Sampel}

Pengambilan sampel di lokasi penelitian dilakukan secara multistage sampling. Dimana jumlah sampel yang nantinya akan diambil sekitar $30 \%$ unit purse seine yang nantinya akan diteliti untuk melihat tingkat efisiensinya. Pengambilan sampel ini menurut Soetriono dan Hanafie (2007) yang dikutip oleh Hiariey (2009) tahapan yang harus diperhatikan adalah sebagai berikut : 1). Pemilihan Kabupaten: pusat-pusat kegiatan perikanan tangkap yang menggunakan alat tangkap purse seine yang masih berkembang dan dominan, yaitu di Kabupaten Maluku Tengah. 2). Pemilihan Kecamatan-kecamatan berdasarkan intensitas kegiatan / aktivitas perikanan yang menggunakan alat tangkap purse seine. 3). Pemilihan sampel secara random dari populasi alat tangkap yang masih aktif beroperasi saat penelitian. Fokus penelitian alat tangkap yang dominan menangkap ikan pelagis kecil salah satunya adalah purse seine.

\section{Metode Analisis Data}

Data yang diperoleh kemudian diolah dan dianalisis secara kuantitatif dan kualitatif, yang ditampilkan dalam bentuk tabel dan grafik. Analisis data kuantiatatif dimaksudkan untuk mengetahui sejauh mana tingkat efisiensi perikanan purse seine. Sedangkan Analisis kualitatif digunakan untuk menjelaskan permasalahn yang terjadi. Teknik analisis data yang dipergunakan untuk menganalisis faktorfaktor yang mempegaruhi efisiensi alat tangkap perikanan purse seine yang diamati adalah dengan memakai fungsi produksi Cob-Dauglas 
dan Fungsi produksi frontier (Stochastic Production Function. Adapun metode-metode yang digunakan antara lain:

Analisis Efisiensi Alat Tangkap

Fungsi Cobb - Dauglas

Model fungsi produksi merupakan persamaan yang melibatkan dua atau lebih variabel yang terdiri dari satu variabel dependent (Y) dan variabel Independent (X). Secara matematik persamaan Cobb-Douglas dapat dituliskan sebagi berikut: $\mathrm{Y}=a X 1^{b 1} X 2^{b 2} X 3^{b 3} \ldots X i^{b i} \ldots X n^{b n} e^{u}$

Bila fungsi Cobb-Dauglas tersebut dinyatakan oleh hubungan $\mathrm{Y}$ dan $\mathrm{X}$, maka:

$\mathrm{Y}=\mathrm{f}(\mathrm{X} 1, \mathrm{X} 2, \ldots \ldots \ldots . . \mathrm{Xi}, \ldots \ldots \ldots . . \mathrm{Xn})$

Dimana:

$\mathrm{Y}=$ Variabel yang dijelaskan

$\mathrm{X}=$ Variabel yang menjelaskan

$\mathrm{a}, \mathrm{b}=$ besaran yang akan diduga

$\mathrm{u}=$ kesalahan (disturbance term)

$\mathrm{e}=$ logaritma natural.

Untuk memudahkan pendugaan maka persamaan tersebut diubah menjadi bentuk linier berganda dengan cara melogaritmakan persamaan tersebut, sehingga menjadi:

$\log \mathrm{Y}=\mathrm{a}+\mathrm{b} 1 \log \mathrm{X} 1+\mathrm{b} 2 \log \mathrm{X} 2+\mathrm{v}$

Perkembangan selanjutnya dari fungsi produksi Cob-Dauglas fungsi produksi frontier yaitu fungsi produksi yang dipakai untuk mengukur bagaimana fungsi sebenarnya terhadap posisi frontiernya (Soekartawi, 1990). Fungsi Produksi Frontier selain diklasifikasikan sebagai deterministic nonparametrik frontier juga dikembangkan teknikteknik lain yang pada dasarnya pengembangan dari fungsi produksi Cob-Dauglas antara lain:

a. Deterministic parametric frontier

b. Deterministic statistical frontier

c. Stochastic frontier

Pendekatan fungsi stochastic production frontier merupakan metode terbaik untuk menghitung efisiensi teknis (TE) alat tangkap, karena unsur ketidakpastian pada perikanan tangkap dapat diakomodir dalam analisis (Aigner, et al,. 1997; Meeusen and van den Broeck 1997; dan Kirkley, et al.,1995 yang dikutip Hiariey, 2009).

Produksi Perikanan tangkap dengan Purse Seine di Kabupaten Maluku Tengah merupakan fungsi dari: panjang alat tangkap ikan, lebar alat tangkap ikan, jumlah nelayan, nilai investasi unit penangkapan, waktu operasi efektif. Secara sistematis persamaan tersebut dapat ditulis sebagai berikut:

$\mathrm{Q}=\mathrm{f}(\mathrm{X} 1, \mathrm{X} 2, \mathrm{X} 3, \mathrm{X} 4, \mathrm{X} 5)$

Untuk menduga faktor-faktor yang berpengaruh terhadap efisiensi alat tangkap maka dilakukan estimasi fungsi produksi Cobb Dauglas. Berdasarkan persamaan 3.3 untuk memberikan gambaran faktor-faktor yang mempengaruhi efisiensi alat tangkap dikembangkan log natural fungsi produksi sebagai berikut:

$\operatorname{Ln}(\mathrm{Q})=\beta 0+\beta 1 \operatorname{Ln}(\mathrm{X} 1)+\beta 2 \operatorname{Ln}(\mathrm{X} 2)+\beta 3$

$\operatorname{Ln}(X 3)+\beta 4 \operatorname{Ln}(X 4)+\beta 5 \operatorname{Ln}(X 5)+v i-u i$

Dimana:

$\mathrm{Qj}=$ rata-rata hasil tangkapan (kg/alat tangkap/trip)

$\mathrm{X} 1$ = panjang alat tangkap ikan (m)

$\mathrm{X} 2$ = lebar alat tangkap ikan $(\mathrm{m})$

$\mathrm{X} 3$ = jumlah nelayan (orang/kapal/trip)

$\mathrm{X} 4=$ nilai investasi unit penangkapan (jutaan rupiah)

X5 = waktu operasi efektif (jam/trip)

vi = gangguan stokastik disebabkan oleh factor eksternal (kondisi cuaca)

ui $=$ variabel random yang sifatnya internal (dapat dikendalikan0 dan berkaitan dengan kapabilitas manejerial nelayan dalam mengelola usaha penangkapan.

Faktor-Faktor Inefisiensi Alat Tangkap

Variabel bebas yang diintegrasikan ke dalam fungsi inefisiensi teknis mengacu pada hasil penelitian Viswanathan et al. (2002) yang dikutip Hiariey, 2009 tentang ketrampilan penangkapan ikan dengan trawl di Malaysia. Variabel tersebut mencakup pengalaman nahkoda, jumlah anggota keluarga, nelayan per kapal, kepemilikan kapal, pendidikan, ukuran kapal, dan penangkapan pada musim puncak. Dengan demikian, spesifikasi fungsi inefisiensi teknis (Ui) dalam penelitian ini diformulasikan sebagai berikut:

$\begin{aligned} \mathrm{Ui}= & \delta 0+\delta 1 A G E+\delta 2 \text { HOUSHOLD }+ \\ & \delta 3 \text { EXPERT }+\delta 4 \text { URSESEINE }+ \\ & \text { } 5 \text { OWNGEAR }+\delta 6 S L T P+\delta 7 S M U+ \\ & \delta 8 U N I V\end{aligned}$

Dimana:

AGE $=$ Umur Nahkoda (tahun)

HOUSHOLD $=$ Jumlah Anggota Keluarga (orang)

EXPERT $=$ Pengalaman Nahkoda (tahun) 
PURSE SEINE $=$ Alat Tangkap

OWNGEAR $=$ Nahkoda Pemilik

SLTP,SMA, UNIV = Pendidikan

Persamaan stochastic production frontier dan fungsi inefisiensi teknis yang diestimasi didasarkan pada hipotesis bahwa nelayan selalu memaksimalkan keuntungan dalam setiap aktivitas penangkapan ikan. untuk menghasilkan parameter yang konsisten maka pendugaan fungsi produksi dan inefisiensi dianalisis secara simultan dengan program frontier 4.1. Estimasi menghasilkan dua kategori, yaitu: (i). Kategori pertama; menduga variabel penjelas yang langsung mempengaruhi produksi (beta 1 - beta 5), bersifat acak dan diasumsikan menyebar normal. (ii). Kategori kedua; variabel yang diasumsi mempengaruhi kapabilitas manajerial nahkoda yang mempengaruhi tingkat inefisiensi dalam usaha penangkapan ikan (delta 1 - delta 9). Variabel ini diasumsikan menyebar setengah normal. Perpaduan kategori 1 dan 2 menghasilkan nilai efisiensi teknis setiap unit sampel yang diteliti.

Indikator Ekonomi Usaha

Keuntungan Usaha

Keuntungan usaha yang diperoleh dihitung dengan mengunakan formulasi sebagai berikut:

$\Pi=\mathrm{TR}-\mathrm{TC}$

Dimana:

$\Pi=$ nilai keuntungan / pendapatan

$\mathrm{TR}=$ penerimaan total (Total Revenue)

$\mathrm{TC}=$ biaya total $($ Total Cost $)$

\section{Penerimaan Total}

Pendapatan total diperoleh dari penerimaan total dikurangi dengan biaya total dalam suatu proses produksi. Adapun total penerimaan diperoleh dari produksi fisik dikalikan dengan harga produk. Maka formulasinya dapat ditulis sebagai berikut:

$\mathrm{TC}=\mathrm{P} \quad \mathrm{x} \quad \mathrm{Q}$

Dimana:

TC = biaya total (total cost)

$\mathrm{P}=$ harga produk (ikan)

$\mathrm{Q}=$ produksi penangkapan ikan.

\section{Biaya}

Biaya menurut Nicholson (1991) adalah pengeluaran yang sepantasnya atau sewajarnya untuk menghasilkan sesuatu barang dan jasa.
Fungsi biaya total adalah sejumlah biaya yang dikeluarkan untk membeli sejumlah kombinasi input yang ditujukan untuk menghasilkan sejumlah output tertentu. Secara matematis, fungsi biaya total sebagai berikut:

$\mathrm{TC}=\mathrm{C}(\mathrm{V}, \mathrm{W}, \mathrm{Q})$

Dimana:

$\mathrm{TC}=$ biaya total

$\mathrm{C}=$ biaya

$\mathrm{W}=$ tingkat harga capital

$\mathrm{Q}=$ tenaga kerja

Menurut Lipsey dan Steiner (1985), biaya merupakan harga produksi yang digunakan untuk ut. Biaya total diperoleh dari penjumlahan biaya variabel (VC) dan biaya tetap (FC). Secara matematis dapat ditulis sebagai berikut:

$\mathrm{TC}=\mathrm{VC}+\mathrm{FC}$

Dimana;

TC = biaya total $($ Total Cost $)$

$\mathrm{VC}=$ biaya variabel (Variable Cost)

$\mathrm{FC}=$ biaya tetap (fixed cost).

Biaya tetap adalah biaya yang dikeluarkan jangka waktu tertentu tanpa dipengaruhi oleh jumlah produksi yang meliputi biaya perizinan melaut, pajak, biaya penyusutan kapal, biaya penyusutan alat tangkap, dan biaya penyusustan mesin. Sedangkan biaya variabel adalah biaya yang selalu beruba-ubah dengan perubahan jumlah produksi yang meliputi bahan bakar, biaya perbekalan, biaya perawatan kapal, biaya perawatan alat tangkap, biaya perawatan mesin, biaya tenaga kerja, dan retribusi (Kesteven, 1973 dikutip oleh Hiariey dan Siahainenia, 1997).

\section{Net Present Value (NPV)}

Net Present Value (NPV) merupakan nilai sekarang (present value) dari selisih antara benefit (manfaat) dengan cost (biaya) pada discount rate tertentu, yang dinyatakan dengan rumus:

$\sum_{i=0}^{n} \frac{B t}{(1+i)^{t}}-\sum_{i=0}^{n} \frac{C t}{(1+i)^{t}}=\sum_{i=0}^{n} \frac{(B t-C t)}{(1+i)^{t}}$

Dimana:

$\mathrm{Bt}=$ Manfaat pada tahun ke- $\mathrm{t}$

$\mathrm{Ct}=$ Biaya pada tahun ke- $\mathrm{t}$

$1 /(1+i)^{t}=$ Discount factor

$\mathrm{T}=\operatorname{tahun}(1,2,3, \ldots ., \mathrm{n})$

$\mathrm{N}=$ Waktu umur proyek 
Apabila evaluasi suatu proyek tertentu telah dinyatakan "Go" maka nilai NPV $\geq 0$. Bila $\mathrm{NPV}=0$, berarti proyek tersebut mengembalikan persis sebesar Social Opportunity Cost of Capital, dan bila NPV <0, maka proyek tersebut "No Go" atau ditolak (Pasaribu, dkk. 2005).

\section{Net Benefit Cost Ratio (Net B/C)}

Net B/C merupakan angka perbandingan antara jumlah nilai sekarang (NPV) positif sebagai pembilang dengan jumlah nilai sekarang (NPV) negatif sebagai penyebut (Pasaribu, $d k k$. 2005). Secara umum formulanya dapat ditulis sebagai berikut:

Net $B / C=\frac{\sum_{t-0}^{n} \frac{B t-C t}{(1+i)^{t}}}{\sum_{t-0}^{n} \frac{C t-B t}{(1+i)^{t}}}$

Dimana:

$\mathrm{Bt}=$ Manfaat pada tahun ke- $\mathrm{t}$

$\mathrm{Ct}=$ Biaya pada tahun ke- $\mathrm{t}$

$1 /(1+i)=$ Discoun factor

Kriterianya adalah:

1) Jika Net $\mathrm{B} / \mathrm{C}$ ratio > 1, maka investasi layak karena memberikan keuntungan

2) Jika Net $B / C$ ratio $=1$, maka usaha tidak untung dan tidak rugi

3) Jika Net $\mathrm{B} / \mathrm{C}<1$, maka investasi tidak layak karena mengalami kerugian

\section{Internal Rate of Return (IRR)}

IRR merupakan alat ukur kemampuan proyek dalam mengembalikan bunga pinjaman dari lembaga keuangan yang membiayai proyek tersebut. Pada dasarnya IRR adalah memperlihatkan present value (PV) benefit akan sama dengan present value (PV) cost dengan kata lain bahwa IRR tersebut menunjukan NPV $=0$ dengan demikian untuk mencari IRR kita harus menaikan Discount Factor (DF) yang merupakan Opportunity Cost of Capital (Pasaribu, dkk. 2005). Secara umum rumusnya adalah sebagai berikut:

$\mathrm{IRR}=\mathrm{i}{ }^{\prime}+\frac{N P V^{\prime}}{N P V^{\prime}-N P V^{\prime \prime}}\left(\mathrm{i}^{\prime},-\mathrm{i}^{\prime}\right)$

Dimana:

$\mathrm{i}$ '= tingkat diskonto yang menghasilkan NPV positif

i"= tingkat diskonto yang menghasilkan NPV negatif

NPV' = NPV positif

NPV" = NPV negatif

Kriterianya adalah:
1) Jika IRR > tingkat bunga berlaku, maka proyek dinyatakan layak

2) Jka IRR < tingkat bunga berlaku, maka proyek dinyatakan tidak layak

\section{Payback Period (PP)}

Analisis payback period (PP) bertujuan untuk mengetahui waktu singkat pengembalian investasi yang telah ditanam pada suatu jenis usaha. Secara umum rumus yang digunakan adalah sebagai beriku (Effendi dan Oktariza, 2006):

$\mathrm{PP}=\frac{\text { Total Investasi }}{\text { Keuntungan }} \times 1$ tahun

\section{Return/Cost (R/C)}

Return/cost $\quad(R / C) \quad$ ratio adalah merupakan perbandingan antara total penerimaan dengan total biaya (Soekartawi, 2001).

$\mathrm{R} / \mathrm{C}=\frac{\text { Total Penerimaan }}{\text { Total Biaya }}$

Dari hasil perhitungan tersebut dapat diperoleh keterangan bahwa semakin besar R/C ratio maka akan semakin besar pula keuntungan yang akan diperoleh. Hal tersebut dapat dicapai apabila alokasi faktor produksi lebih efisien.

Analisis Titik Impas (Break Event Point)

Analisis titik impas atau dapat disebut Break Event Point (BEP) dimana dapat diperhitungkan batas kuatitas produksi yang mengalami keuntungan dan kerugian pada usaha perikanan yang dilakukan oleh petani/nelayan (Pasaribu, $d k k, 2005$ ). Ada 2 bentuk analisis titik impas, yaitu :

1) BEP Produksi $=\frac{\text { Total Biaya }}{\text { Harga Penjualan }}$

2) BEP Harga $=\frac{\text { Total Biaya }}{\text { Total Produksi }}$

\section{Analisis SWOT}

Dalam melihat peluang pengembangan dan meminimalisir kelemahan dan ancaman dalam pengembangan usaha perikanan purse seine di wilayah Kabupaten Maluku Tengah dan sekitarnya, maka yang kita perlu membuat suatu analisis yang disebut dengan nama "Analisis SWOT". Adapun langkah-langkah yang perlu diambil dalam menganalisis SWOT adalah dengan mengidentifikasi faktor-faktor internal (faktor dari dalam) dan faktor-faktor 
eksternal (faktor dari luar) yang mempengaruhi pengembangan usaha perikanan purse seine di wilayah Kabupaten Maluku Tengah dan sekitarnya.

\section{HASIL DAN PEMBAHASAN \\ Status Pemanfaatan Sumberdaya}

Ketersedian potensi sumberdaya ikan dalam pengelolaan sumberdaya ikan pelagis kecil merupakan salah satu aspek biologi. Jika sumberdaya ikan masih tersedia, maka usaha penagkapan ikan pelagis kecil dengan purse seine dapa dilakukan.

Dari data yang ada untuk Maluku Tengah, pada tahun 2010, 2011 dan 2012 terjadi effort dan produksinya tinggi, tetapi CPUE yang diperoleh rendah. Sedangkan pada tahun 2008 dan 2009 hasil CPUE yang diperoleh merupakan hasil tertinggi dengan effort masing-masing adalah sebanyak 636 trip per tahun dan 668 trip per tahun. Namun, jika dilihat dari lima (5) tahun produksi yang memiliki produksi paling tertinggi adalah pada tahun 2011 dengan produksi sebesar 22.986 ton dengan effort sebesar 5.039 trip per tahun. Untuk melihat lebih jelas tentang Perkembangan Produksi, Upaya Penangkapan dan CPUE dapat dilihat pada Tabel 1.

Tabel 1. Perkembangan Produksi, Upaya Tangkapan dan CPUE Ikan Pelagis Kecil di Kabupaten Maluku Tengah Tahun 2008-2012

\begin{tabular}{crrrrr}
\hline Tahun & Produksi (Kg) & Produksi (ton) & \multicolumn{1}{c}{ Effort (trip) } & CPUE (Kg) & CPUE (ton) \\
\hline 2008 & 23.849 .100 & $23.849,1$ & 4.973 & $4.795,716$ & 4,795 \\
2009 & 21.344 .900 & $21.344,9$ & 5.222 & $4.087,495$ & 4,087 \\
2010 & 18.984 .800 & $18.984,8$ & 18.401 & $1.031,726$ & 1,031 \\
2011 & 24.413 .400 & $24.413,4$ & 17.247 & $1.415,515$ & 1,415 \\
2012 & 25.321 .500 & $25.321,5$ & 18.252 & $1.387,327$ & 1,387 \\
\hline Jumlah & $\mathbf{1 1 3 . 9 1 3 . 7 0 0}$ & $\mathbf{1 1 3 . 9 1 3 , 7}$ & $\mathbf{6 4 . 0 9 5}$ & $\mathbf{1 2 . 7 1 7 , 7 7 9}$ & $\mathbf{1 2 , 7 1 5}$ \\
\hline Rata-rata & $\mathbf{2 2 . 7 8 2 . 7 4 0}$ & $\mathbf{2 2 . 7 8 3}$ & $\mathbf{1 2 . 8 1 9}$ & $\mathbf{2 . 5 4 4}$ & $\mathbf{3}$ \\
\hline
\end{tabular}

Sumber: Data Primer diolah, 2013

Berdasarkan perhitungan hubungan antara CPUE dan effort purse seine dalam pemanfaatan sumberdaya ikan pelagis kecil, maka diperoleh nilai intersep $(\alpha)$ sebesar 5.698,597 dan koefisien independent $(b)$ sebesar $-0,2461$. Secara matematis hubungan antara CPUE dengan effort purse seine dapat dinyatakan sebagai berikut: CPUE $=2.849,30$ ton/hari kapal. Hubungan antara hasil dengan effort yang lebih dikenal sebagai fungsi produksi lestari dapat dinyatakan sebagai berikut $h=32.985 .654$ ton/tahun. Sementara untuk Kota Ambon, pada tahun 2010, 2011 dan
2012 terjadi effort dan produksinya tinggi, tetapi CPUE yang diperoleh rendah. Sedangkan pada tahun 2008 dan 2009 hasil CPUE yang diperoleh merupakan hasil tertinggi dengan effort masing-masing adalah sebanyak 4.973 trip dan 5.222 trip. Namun, jika dilihat dari lima (5) tahun produksi yang memiliki produksi paling tertinggi adalah pada tahun 2012 dengan produksi sebesar 25.321,5 ton dengan effort sebesar 18.252 trip per tahun. Untuk melihat lebih jelas tentang Perkembangan Produksi, Upaya Penangkapan dan CPUE dapat dilihat pada Tabel 2.

Tabel 2. Perkembangan Produksi, Upaya Tangkapan dan CPUE Ikan Pelagis Kecil di Kota Ambon Tahun 2008 - 2012

\begin{tabular}{crrrrr}
\hline Tahun & Produksi (Kg) & Produksi (ton) & Effort (trip) & CPUE (Kg) & CPUE (ton) \\
\hline 2008 & 11.804 .800 & $11.804,8$ & 636 & $18.561,006$ & 18,561 \\
2009 & 10.565 .300 & $10.565,3$ & 668 & $15.816,317$ & 15,816 \\
2010 & 19.275 .500 & $19.275,5$ & 11.089 & $1.738,254$ & 1,738 \\
2011 & 22.986 .900 & $22.986,9$ & 5.114 & $4.494,720$ & 4,494 \\
2012 & 21.819 .900 & $21.829,9$ & 5.039 & $4.330,204$ & 4,330 \\
\hline Jumlah & $\mathbf{8 6 . 4 1 5 . 5 0 0}$ & $\mathbf{8 6 . 4 5 1 , 5}$ & $\mathbf{2 2 . 5 4 6}$ & $\mathbf{4 4 . 9 4 0 , 5 0 1}$ & $\mathbf{4 4 , 9 3 9}$ \\
\hline Rata-rata & $\mathbf{1 7 . 2 9 0 . 3 0 0}$ & $\mathbf{1 7 . 2 9 0}$ & $\mathbf{4 . 5 0 9}$ & $\mathbf{8 . 9 8 8}$ & $\mathbf{9}$ \\
\hline
\end{tabular}

Sumber: Data Primer diolah, 2013 
Berdasarkan perhitungan hubungan antara CPUE dan effort purse seine dala pemanfaatan sumerdaya ikan pelagis kecil, maka diperoleh nilai intersep $(\alpha)$ sebesar dan koefisien independent (b) sebesar -1,5767. Secara matematis hubungan antara CPUE dengan effort purse seine dapat dinyatakan sebagai berikut: $\mathrm{CPUE}=8.048,77$ ton/hari kapal. Hubungan antara hasil dengan effort yang lebih dikenal sebagai fungsi produksi lestari dapat dinyatakan sebagai berikut $h=$ 41.008.769 ton/tahun.

\section{Efisiensi Teknis Perikanan Purse Seine}

Efisiensi Teknis Penangkapan

Efisiensi teknis merupakan ukuran dari kemampuan produksi yang terbaik serta keluaran optimal yang mungkin dicapai dari berbagai masukan teknologi yang digunakan (Viswananthan et.al., 2003). Pada analisis fungsi produksi Cobb-Douglas stochastic frointier, terdapat 5 (lima) variabel yang diduga berperan penting dalam produksi. Setelah dianalisis menggunakan teknik MLE, variabel panjang dan lebar alat tangkap, jumlah nelayan ABK, nilai investasi dan waktu operasi efektif memberikan respon nyata dengan arah sama terhadap produksi ikan pelagis kecil.

Hasil penelitian mengindikasikan bahwa nelayan yang telah berpengalaman dalam operasi penangkapan ikan, tidak selalu dapat mencapai tingkat efisiensi yang diharapkan. Dalam konteks tersebut, variasi produktivitas akan muncul walaupun nelayan menggunakan teknologi penangkapan yang sama, dan musim yang sama. Hal ini disebabkan produksi ikan pada hakekatnya merupakan sebuah perpaduan dari berbagai faktor internal yang dapat dikendalikan maupun faktor eksternal yang tidak dapat dikendalikan. Faktor eksternal mencakup sumberdaya ikan, musi, arus, angin dan ombak. Sedangkan faktor internal mencakup kapabilitas manajerial dalam usaha penangkapan ikan. Faktor ini mencakup tingkat penguasaan teknologi penangkapan, penanganan produksi dan kemampuan untuk mengumpul dan menganalisis informasi perikanan yang relevan dengan usaha penangkapannya, untuk menghasilkan penagambilan keputusan yang lebih efektif.
Manfaat informasi dapat dipahami melalui kemampuan manajerial nelayan yang diwujudkan dalam penerapan teknologi penangkapan ikan. Dalam hal ini, mencakup aspek efisiensi teknis dalam penggunaan teknologi penangkapan, penggunaan faktor produksi, dan prediksi daerah penangkapan potensial.

Berdasarkan penjelasan di atas, maka bagian ini akan menganalisis fungsi stochastic production frontier, determinan-detrminan yang mempengaruhi produksi ikan, sekaligus menganalisis variabel yang diduga mempengaruhi kemampuan manjerial nelayan serta faktor penyebab inefisiensi dalam pengelolaan usaha perikanan purse seine di Kabupaten Maluku Tengah dan Kota Ambon. Dengan demikian, dapat dihasilkan faktor produksi yang berpotensi meningkatkan produksi ikan dan faktor-faktor yang berpotensi dapat mengurangi inefsiensi teknis penangkapan.

\section{Determinan Efisiensi Teknis Penangkapan}

Tabel 3 menunjukan variabel panjang alat tangkap memberikan pengaruh nyata dan bernilai negatif di dalam model fungsi stochastic production frontier. Sedangkan untuk lebar alat tangkap memiliki pengaruh nyata secara positif di dalam model ini. Dengan adanya perbedaan antara panjang dan lebar alat tangkap maka akan berpengaruh juga terhadap hasil tangkapan. Untuk variabel jumlah ABK memberikan pengaruh nyata dan bernilai negative terhadap fungsi produksi. Hal ini berarti dengan adanya penambahan jumlah ABK dalam suatu operasi penangkapan, maka akan berpeluang menurunkan hasil tangkapan. Untuk variabel investasi memberikan pengaruh nyata dan bernilai positif terhadap fungksi produksi. Jumlah modal investasi menentukan ukuran dan kualitas unit penangkapan. Dengan kata lain, ukuran kapal yang lebih besar dapat menjangkau daerah penangkapan yang lebih jauh, sehingga berpeluang untuk meningkatkan hasil tangkapan. Untuk variabel waktu operasi memberikan pengaruh yang nyata dan positif terhadap fungsi produksi. Hal ini berarti dengan adanya penambahan waktu yang lama, maka akan memberikan hasil yang baik terhadap hasil tangkapan. Rata-rata tingkat efisiensi 
teknis penangkapan perikanan purse seine adalah sebesar 0,48 pada periode tahunan.

Tabel 3. Hasil Estimasi Fungsi Produksi Frontier Perikanan Purse Seine di Kabupaten Maluku Tengah dan Kota Ambon

\begin{tabular}{llrrrr}
\hline No & \multicolumn{1}{c}{ Variabel } & Parameter & Koefisien & Stand-Error & \multicolumn{1}{c}{ t-rasio } \\
\hline 1. & Konstanta & $\beta 0$ & 0,5768 & 0,1280 & 0,4506 \\
2. & LX1 (Panjang Alat) & $\beta 1$ & $-0,1175$ & 0,2176 & $-0,5402$ \\
3. & LX2 (Lebar Alat) & $\beta 2$ & 0,9004 & 0,3489 & 0,2580 \\
4. & LX3 (Jumlah ABK) & $\beta 3$ & 0,4802 & 0,3570 & $-0,1345$ \\
5. & LX4 (Investasi) & $\beta 4$ & 0,3138 & 0,4569 & 0,6867 \\
6. & LX5 (Waktu Operasi) & $\beta 5$ & 0,2362 & 0,1700 & 0,1389 \\
7. & Log Likelihood & - & $-0,4740$ & - & - \\
8 & Mean Efisiensi Teknis & - & 0,4828 & - & - \\
9. & LR test of the one-side error & - & 0,2071 & - & - \\
10. & Total Sampel & - & 57 & - & - \\
\hline
\end{tabular}

Sumber: Data Primer diolah, 2013

Keterangan: Taraf nyata $\alpha=0.05$ dan $\alpha=0.01$

Determinan Fungsi Inefisiensi Teknis Penangkapan

Hasil analisis (Tabel 4) menunjukan bahwa terdapat masalah inefisiensi teknis dalam penangkapan ikan dengan menggunakan alat tangkap purse seine pada periode tahunan. Variabel umur pada periode tahunan ini tidak memberikan pengaruh nyata dan bertanda negatif. Hal ini mengindikasikan bahwa semakin tua umur nahkoda, maka kemampuan manajemen operesi penangkapan semakin menurun sebagai konsekuensi penurunan kondisi fisik, walaupun pengalamannya terus bertambah. Untuk variabel jumlah anggota keluarga memberikan respons negatif yang nyata terhadap inefisiensi penangkapan ikan pada periode tahunan. Hal ini mengindikasikan bahwa dalam konteks jumlah anggota keluarga berkaitan dengan ketersediaan tenaga kerja per waktu, maka jumlah anggota keluarga yang lebih besar adalah cenderung lebih efisien dalam hal ketersediaan tenaga kerja nelayan. Sebaliknya, jika jumlah perempuan dan anak usia muda lebih banyak dalam keluarga, akan menimbulkan inefisinsi penangkapan karena ketersediaan tenaga kerja nelayan terbatas dan pekerjaan sebagai nelayan penangkapan di likasi didominasi oleh tenaga kerja laki-laki. Variabel Pengalaman nahkoda memberikan pengaruh positif dan nyata terhadap inefisiensi penangkapan ikan pada periode tahunan. Pengalaman sebagai nahkoda dalam penangkapan ikan berkaitan dengan informasi mengenai ruaya ikan dan kondisi arus laut. Informasi ini membantu nahkoda dalam menentukan lokasi daerah penangkapan ikan yang lebih tepat, sehingga efisiensi teknis dapat ditingkatkan.

Variabel purse seine menunjukan pengaruh nyata dan negatif terhadap inefisiensi teknis penangkapan. Untuk variabel nahkoda pemilik memberikan pengaruh nyata dan positif terhadap inefisiensi teknis penangkapan ikan. Untuk variabel pendidikan nahkoda dan variabel universitas memberikan pengaruh yang nyata dan positif terhadap inefisiensi teknis penangkapan. Hal ini mengindikasikan bahwa pendidikan yang lebih tinggi terhadap efisiensi teknis mengindikasikan peranan pendidikan sebagai human capital dan merupakan salah satu faktor penting bagi kemampuan manajerial nahkoda. Hal ini berkaitan dengan kemampuan professional dan disiplin nahkoda dalam meningkatkan efisiensi alokasi input dalam penangkapan ikan. Dengan demikian, tingkat kemampuan nahkoda secara individu adalah berkaitan dengan taraf pendidikan. 
Tabel 4. Hasil Estimasi Fungsi Inefisiensi Teknis Perikanan Purse Seine di Kabupaten Maluku Tengah dan Kota Ambon

\begin{tabular}{llrrrr}
\hline No. & Variabel & Parameter & Koefisien & Stand-Error & \multicolumn{1}{c}{ t-rasio } \\
\hline 1. & Konstanta & $\delta 0$ & $-0,8065$ & 0,9795 & $-0,8234$ \\
2. & Umur & $\delta 1$ & $-0,3851$ & 0,4901 & $-0,7857$ \\
3. & Jumlah $\quad$ Angg. & $\delta 2$ & $-0,5953$ & 0,7938 & $-0,7499$ \\
& Keluarga & & & & \\
4. & Pengalaman & $\delta 3$ & 0,1084 & 0,4191 & 0,2586 \\
& Nahkoda & & & & \\
5. & Purse Seine & $\delta 4$ & $-0,1902$ & 0,4294 & $-0,4430$ \\
6. & Nahkoda Pemilik & $\delta 5$ & 0,4515 & 0,5987 & 0,7542 \\
7. & Pendidikan Nahkoda & $\delta 6$ & 0,1227 & 0,5435 & 0,2258 \\
8. & Universitas & $\delta 7$ & 0,4892 & 0,1028 & 0,4757 \\
9. & Log Likelihood & - & $-0,4740$ & & - \\
10. & Sigma-squared & - & 0,1305 & 0,2891 & 0,4515 \\
11. & Gamma & - & 0,9999 & 0,9654 & 0,1035 \\
12. & Total Sampel & - & 57 & & - \\
\hline
\end{tabular}

Sumber: Data Primer diolah, 2013

Keterangan: Taraf nyata $\alpha=0.05$ dan $\alpha=0.01$

\section{Indikator Ekonomi Usaha}

Biaya Tetap

Biaya tetap adalah biaya yang dikluarkan dalam jangka waktu tertentu tanpa dipengaruhi oleh jumlah produksi. Biaya tetap terdiri dari biaya penyusutan (depresiasi), perbaikan/peawatan, dan administrasi. Biaya penyusutan (depresiasi) merupakan pengalokasian biaya investasi dari suatu unit usaha setiap tahun sepanjang umur ekonomis dari unit usaha tersebut. Biaya penyusutan ini tidak mengandung unsur pengeluaran uang, tetapi berhubungan dengan faktor depresiasi modal akibat bertambahnya umur unit usaha. Biaya penyusutan (depresiasi) diperoleh dengan cara mengurangi nilai investasi dengan nilai sisa kemudian dibagi estimasi umur ekonomis alat tangkap yang digunakan. Dalam penelitian yang dilakukan, didapatkan bahwa umur pemakaian (umur ekonomis) untuk kapal/body adalah sekitar 10 tahun, umur pemakaian (umur ekonomis) untuk mesin adalah sekitar $8-15$ tahun, dan umur pemakaian (umur ekonomis) untuk jaring adalah sekitar 10 - 20 tahun. Berikut ini adalah rincian biaya tetap (biaya penyusutan dan biaya perawatan/perbaikkan).

Berdasarkan hasil yang diperoleh dapat diketahui bahwa jumlah biaya penyusutan dari masing-masing unsur baik itu kapal, mesin dan jaring sangat jauh berbeda. Dimana yang memiliki biaya penyustutan (depresiasi)tertinggi adalah jaring sebesar Rp. 309.631.111,-/tahun dengan nilai rata-rata sebesar Rp. 897.930.229,-/tahun. Kemudian diikuti dengan mesin dengan biaya penyusutan sebesar Rp. 495.502.180,-/tahun dengan nilai rata-rata sebesar Rp. 17.086.282,-/tahun dan untuk yang terendah adalah kapal/body dengan biaya penyusutan sebesar Rp. 9.571.428,/tahun dengan nilai rata-rata sebesar $\mathrm{Rp}$. 12.435.300,-/tahun. Dengan demikan total jumlah biaya tetatp untuk biaya penyusutan (depresiasi) unit purse seine di wlayah Maluku Tengah dan sekitarnya adalah sebesar Rp. 2.109.748.408,-/tahun dengan nilai rata-rata sebesar Rp. 72.749.945,-/tahun.

Untuk biaya perwatan/perbaikkan dapat diketahui bahwa jumlah biaya perawatan/perbaikan dari setiapa unsur baik itu kapal, mesin dan jaring sangatlah berbeda. Dimana terlihat bahwa yang memiliki biaya perawatan/perbaikan tertinggi adalah transport dengan biaya sebesar Rp. 934.752.000,-/tahun dengan nilai rata-rata sebesar Rp.17.399.157,/tahun. Berikutnya adalah jaring dengan biaya perawatan/perbaikkan sebesar Rp. 376.200.000,-/tahun dengan nila rata-rata sebesar Rp. 13.972.413,-/tahun. Untuk jaring perawatan dilakukan setiap 2 bulan 1 kali dalam setahun, jadi selebihnya 6 kali melakukan perawatan/perbaikan. Berikutnya adalah kapal dengan biaya perawatan/perbaikkan sebesar Rp. 343.900.000,-/tahun dengan nilai rata-rata 
sebesar Rp.12.858.620,-/tahun. Untuk perawatn/perbaikkan kapal biasanya dilakukan setiap 2 bulan 1 kali dalam setahun, jadi sebanyak 6 kali dalam setahun melakukan perawatan/perbaikkan untuk kapal. Dan untuk mesin memiliki biaya perawatan/perbaikkan yang paling terendah adalah sebesar Rp. 214.652.000,-/tahun dengan nilai rata-rata sebesar Rp. 7.401.793,-/tahun. Untuk perawatan/perbaikkan mesin dilakukan $4-6$ bulan 1 kali dalam setahun, jadi sekitar $2-3$ kali dalam setahun melakukan perawatan/perbaikkan terhadap mesin. Dengan demikian total jumlah biaya tetap untuk biaya perawatan/perbaikkan untuk unit purse seine di wilayah Maluku Tengah dan sekitarnya adalah sebesar Rp. 974.252.000,-/tahun dengan nilai rata-rata sebesar Rp. 34.594.896,-/tahun.

\section{Biaya Variabel}

Biaya variabel adalah biaya yang selalu berubah-ubah sesuai dengan perubahan jumlah produksi. Biaya variabel merupakan biaya yang harus dikeluarkan suatu usaha penangkapan ikan untuk membiayai kegiatan penangkapan, seperti BBM (Bensin, Minyak Tanah, dan Oli). Besarnya biaya variabel yang dikeluarkan tergantung pada waktu penangkapan dan jumlah tenaga kerja.

Berdasarkan hasil yang diperoleh dapat diketahui bahwa biaya variabel yang dikeluarkan oleh setiap unit purse seine di wilayah Maluku Tengah dan sekitarnya sangat berbeda. Dimana biaya variabel tertinggi adalah bahan bakar oli dengan nilai sebesar Rp. 25.250.000,-/tahun dengan nilai rata-rata sebsesar Rp. 442.982,45,-. Sedangkan biaya variabel terendah adalah bahan bakar bensin dengan nilai sebesar Rp. 4.930.000,- dengan nilai rata-rata sebesar Rp. 86.491,22,-/tahun. Biaya pemakaian bahan bakar minyak untuk kebutuhan operasi melaut yang dilakukan dengan waktu penangkapan dan jarak dari lokasi pendaratan ke daerah penangkapan (fishing ground) yang relative berbeda, sehingga menyebabkan yang dialokasikan pun bervariasi. Untuk jumlah rata-rata frekuensi melaut yang dilakukan oleh unit purse seine pada musim barat (musim ikan) sebanyak 17 kali dalam sebulan dan pada musim timur (musim kurang ikan) rata-rata frekuensi melaut sebanyak 19 kali dalam sebulan.
Pendapatan

Hasil yang diperoleh dari penjualan dalam satu kaliperesi penangkapan disebut dengan "Pendapatan". Dalam suatu usaha penangkapan ikan, biasanya diterapkan sistem bagi hasil yang merupakan kesepakatan bersama antara nelayan pemilik dengan para ABK dan pemilik rumpon. Pendapatan yang diperoleh ABK di Wilayah Maluku Tengah dan sekitarnya dibagi secara merata, namun tidak disangkal juga bahwa pendapatan yang akan diterima bergantung pada berapa banyak frekuensi/hari melaut dari masing-masaing ABK. Hasil usaha yang dibagi tersebut merupakan pendapatan bersih yaitu pendapatan kotor setelah dikurangi dengan biaya operasional (BBM dan rumpon). Berdasarkan wawancara yang dilakukan diketahui bahwa pendapatan bersih yang didapat oleh nelayan pemilik adalah berkisar antara Rp 10.000.000,- Rp. 15.000.000,-/bulan. Sedangkan untuk ABK dan rumpon pendapatan yang diperoleh adalah berkisar antara Rp. 500.000,- - Rp. 1.500.000,-/bulan.

\section{Analisis Kelayakan Usaha}

Dari Tabel 5 terlihat bahwa nilai NPV pada DF $13 \%$ pada perikanan purse seine di Kabupaten Maluku Tengah dan Kota Ambon adalah sebesar Rp 30. 514.684,- . Ini berarti bahwa nilai NPV-nya bernilai positif, dimana NPV > 0. Hal ini berarti unit usaha purse seine di Kabupaten Maluku Tengah dan Kota Ambon dapat memberikan nilai keuntungan yang lebih besar dari biaya yang telah dikeluarkan, sehingga biaya investasi usaha purse seine dapat diterima.

Hasil nilai IRR dari Tabel 5, menunjukan bahwa nilai yang diperoleh uni usaha purse seine di Kabupaten Maluku Tengah dan Kota Ambon adalah sebesar $23,97 \%$. Hal ini berarti bahwa presentase nilai IRR-nya lebih besar dari tingkat suku bunga yang ditentukan yaitu sebesar 13\%. Dengan demikian dapat dikatakan bahwa investasi dapat diterima karena IRR-nya lebih besar dari rate of return yang dikehendaki.

Nilai $\mathrm{B} / \mathrm{C}$ ratio yang diperoleh dalam investasi usaha perikanan purse seine adalah sebesar 1,519. Ini berarti bahwa setiap Rp 1,00 biaya yang dikeluarkan akan dikembalikan sebesar Rp 1,519. Untuk titik impas dari hasil 
penjualan adalah sebesar $\operatorname{Rp} 6.606,-$ dan untuk hasil tangkapan adalah sebesar $3.765 \mathrm{~kg}$. sedangkan untuk jangka waktu pengembalian modal investasi usaha perikanan purse seine di Kabupaten Maluku Tengah dan Kota Ambon berdasarkan hasil analisis adalah sebesar 2,16 tahun.
Dengan demikian dari segi financial, usaha perikanan purse seine di Kabupaten Maluku Tengah dan Kota Ambon layak untuk dikembangkan. Hal ini berarti bahwa bagi pengusaha (nelayan) yang mengambil keputusan menginvestasikan modalnya pada usaha perikanan purse seine adalah satu keputusan yang menguntungkan saat ini.

\section{Tabel 5. Hasil Kriteria Investasi Usaha Perikanan Purse Seine} di Kabupaten Maluku Tengah dan Kota Ambon

\begin{tabular}{llcc}
\hline No & \multicolumn{1}{c}{ Kriteria Penilaian } & Nilai & Justifikasi Kelayakan \\
\hline 1. & Net Present Value (NPV) & Rp $30.514 .684,-$ & $>0$ \\
2. & Internal Rate of Return (IRR) & $23,97 \%$ & $>$ discount rate \\
3. & Net Benefit-Cost Ratio (Net B/C) & 1,519 & $>1$ \\
4. & Break Event Point Harga (Rp) & 6.606 & Impas \\
& (BEP Harga) & & \\
5. & Break Event Point Produksi (Kg) & 3.765 & Impas \\
& (BEP Produksi) & & $>1$ \\
6. & Payback Period (PP) & 2,16 & \\
\hline
\end{tabular}

\section{Analisis SWOT}

Setelah hasil analisis dari faktor-faktor internal dan ekternal didapat, selanjutnya dilakukan analisis alternative strategi pengembangan dengan menggunakan "Matriks SWOT" guna dan untuk melihat keterkaitan antara faktor-faktor internal dengan faktor-faktor eksternal (Tabel 6).

\section{Tabel 6. Hasil Analisis Matriks SWOT}

\begin{tabular}{|c|c|c|}
\hline Faktor Eksternal & $\begin{array}{l}\text { Kekuatan (S) } \\
\text { 1). Potensi sumberdaya ikan } \\
\text { 2). Adanya pengalaman yang cukup } \\
\text { baik mengenai teknik } \\
\text { pengoperasian unit penangkapan } \\
\text { purse seine. } \\
\text { 3). Tersedianya tempat pendaratan } \\
\text { ikan. } \\
\text { 4). Tenaga kerja (ABK) untuk unit } \\
\text { purse seine banyak tersedia. } \\
\text { 5). Usaha purse seine secara } \\
\text { ekonomi layak untuk } \\
\text { dikembangkan. } \\
\text { 6). Dukungan Kebijakan Pemerintah } \\
\text { daerah. } \\
\text { 7). Prorgram bantuan Pemerintah } \\
\text { Daerah. }\end{array}$ & $\begin{array}{l}\text { Kelemahan }(\mathbf{W}) \\
\text { 1). Tingakat pengetahuan nelayan } \\
\text { dalam memanfaatkan potensi } \\
\text { yang tersedia masih sangat } \\
\text { kurang/terbatas. } \\
\text { 2). Kualitas SDM (nelayan) masih } \\
\text { rendah. } \\
\text { 3). Kualitas produk rendah. } \\
\text { 4). Terbatasnya sarana alat } \\
\text { penangkapan pendukung } \\
\text { perikanan. } \\
\text { 5). Akses modal terbatas. } \\
\text { 6). Sistem pemasaran belum } \\
\text { memadai }\end{array}$ \\
\hline $\begin{array}{l}\text { Peluang ( O) } \\
\text { 1). Tersedianya paket-paket bantuan } \\
\text { dari pihak Pemerintah maupun } \\
\text { Swasta. } \\
\text { 2). Permintaan pasar terhadap } \\
\text { komoditi perikanan terus } \\
\text { meningkat, baik dipasar lokal } \\
\text { maupun eksport. } \\
\text { 3). Penerapan teknologi tepat guna } \\
\text { dalam proses penangkapan. } \\
\text { 4). Perhatian Investor } \\
\text { 5). Prasarana Penangkapan. }\end{array}$ & $\begin{array}{l}\text { Strategi (SO) } \\
\checkmark \text { Pengembangan Pendampingan } \\
\text { pada kelompok nelayan. } \\
\checkmark \text { Pengembangan teknologi tepat } \\
\text { guna untuk penanganan hasil } \\
\text { tangkapan. } \\
\checkmark \text { Peningkatan produksi perikanan. } \\
\checkmark \text { Pengembangan infrastruktur. }\end{array}$ & $\begin{array}{l}\text { Strategi (WO) } \\
\checkmark \text { Penyediaan sarana dan pra- } \\
\text { sarana pendukung penangkapan. } \\
\checkmark \text { Meningkatkan dan menguatkan } \\
\text { kapasitas Sumber Daya Manusia } \\
\text { (SDM) melalui pelatihan, } \\
\text { pendidikan dan kelembagaan. } \\
\checkmark \text { Pemeberdayaan dan penguatan } \\
\text { masyarakat melalui bantuan } \\
\text { kredit usaha untuk nelayan. }\end{array}$ \\
\hline
\end{tabular}




\begin{tabular}{|c|c|c|}
\hline $\begin{array}{l}\text { Ancaman (T) } \\
\text { 1). Terjadinya Overfishing di } \\
\text { perairan Maluku Tengah dan } \\
\text { Kota Ambon. } \\
\text { 2). Produksi berfluktuasi. } \\
\text { 3). Masuknya nelayan dari daerah } \\
\text { lain untuk melakukan kegiatan } \\
\text { penangkapan di wilayah tersebut } \\
\text { yang bersifat IUUF. } \\
\text { 4). Meningkatnya biaya operasional } \\
\text { 5). Perdagangan ikan di tengah laut. }\end{array}$ & $\begin{array}{ll}\text { Strategi (ST) } \\
\checkmark \text { Pembatasan dan pengawasan } \\
\text { terhadap ijin penangkapan ikan. } \\
\checkmark \text { Peningkatan } \quad \text { efisiensi } \\
\quad \text { penangkapan unit purse seine. }\end{array}$ & $\begin{array}{l}\text { Strategi (WT) } \\
\checkmark \text { Peningkatan pengawasan } \\
\text { ditingkat Pemerintah dan } \\
\text { Masyarakat } \\
\checkmark \text { Perlu analisis CPUE untuk } \\
\text { mengamati perkembangan } \\
\text { potensi sumberdaya ikan. }\end{array}$ \\
\hline
\end{tabular}

\section{KESIMPULAN}

1. Faktor-faktor yang mempengaruhi perikanan purse seine di Kabupaten Maluku Tengah dan Kota Ambon adalah investasi, panjang jaring dan jumlah ABK. Dimana ketiga faktor produksi tersebut memiliki pengaruh terhadap hasil tangkapan yang diperoleh.

2. Estimasi efisiensi teknis penangkapan dengan analisi SPF (Stochastic Production Frontier) hasil tangkapan untuk perikanan purse seine di Kabupaten Maluku Tengah dan Kota Ambon dipengaruhi oleh panjang dan lebar alat tangkap, jumlah nelayan, nilai investasi dan waktu operasi penangkapan. Dimana nilai rata-rata efisiensi teknis penangkapan adalah sebesar. 0,48. Selenjutnya, untuk inefisiensi teknis penangkapan dipengaruhi oleh umur nahkoda, jumlah anggota keluarga, pengalaman nahkoda, alat tangkap purse seine, nahkoda pemilik dan pendidikan nahkoda. Untuk keberlanjutan usaha perikanan purse seined Kabupaten Maluku Tengah dan Kota Ambon layak untuk dikembangkan. Dengan rata-rata nilai NPV sebesar Rp. 30.514.684.- /tahun, IRR sebesar 23,97\%, nilai $\mathrm{B} / \mathrm{C}$ ratio sebesar 5,85 . Rata-rata jangka waktu pengembalian modal investasi (PP) berdasarkan hasil analisis adalah sebesar 2,16 tahun, dengan BEP harga sebesar Rp. 6.606,- dan BEP produksi sebesar Rp. 3.765,-

3. Strategi kebijakan pengembangan perikanan purse seine di Kabupaten Maluku Tengah dan Kota Ambon yang utama adalah menggunakan kekuatan yang dimilki dengan menggunakan kekuatan yang dimiliki dengan memanfaatkan peluang yang ada. Strategi kebijakan tersebut mencakup pengembangan pendampingan pada kelompok nelayan, pengembangan teknologi tepat guna untuk penanganan hasil tangkapan, dan peningkatan produksi perikanan. Prioritas kedua, strategi kebijakan adalah memanfaatkan seluruh kekuatan untuk menghindari ancaman. Dimana strategi kebijakannya adalah pengembangan cold storage. Prioritas ketiga, strategi kebijakan adalah memanfaatkan peluang yang ada dengan mengatasi masalah yang dimiliki. Kebijakannya adalah mencakup penyediaan sarana dan pra-sarana pendukung penangkapan. Selanjutnya meningkatkan dan menguatkan kapasitas sumberdaya manusia (SDM) melalui pelatihan, pendidikan dan kelembagaan. Untuk prioritas terakhir adalah meminimalkan kelemahan dan menghindari ancaman. Kebijakan ini meliputi peningkatan pengawasan di tingkat Pemerintah dan Masyarakat dan perlu analisis CPUE untuk mengamati perkembangan potensi sumberdaya ikan.

\section{SARAN}

1. Bagi pihak Pemerintah perlu mengembangkan sarana dan pra-sarana penunjang untuk perikanan purse seine di Kabupaten Maluku Tengah dan Kota Ambon.

2. Perlu ada bantuan-bantuan berupa alat tangkap perikanan purse seine yang tepat sasaran, agar dapat digunakan oleh nelayan dengan sebaik mungkin demi meningkatkan kesejahteraan hidup.

3. Dalam meningkatkan efisiensi teknis penangkapan, maka eksploitasi terhadap sumberdaya ikan peru mempertimbangkan faktor musim tangkap, alokasi optimal alat tangkap, dan faktor manajerial dalam operasi penangkapan. 


\section{DAFTAR PUSTAKA}

[BRKP] Badan Riset Kelautan Perikanan dan LIPI, Jakarta. 2001. Pengkajian Stok Ikan di Perairan Indonesia. Kerjasama PRPT-BRKP-DKP dan PPPO-LIPI. Jakarta. 125 hal.

[DKP RI] Dinas Kelautan dan Perikanan Republik Indonesia. 2006. Statistik Kelautan dan Perikanan Tahun 2005. Departemen Kelautan dan Perikanan, Republik Indonesia.

[DKP Maluku] Dinas Kelautan dan Perikanan Maluku. 2007. Laporan Tahunan 2005. Dinas Perikanan dan Kelautan Provinsi Maluku. Ambon.

Effendi I dan Oktariza W. 2006. Manajemen Agribisnis Perikanan. Penerbit: Penebar Swadaya. Jakarta.

Hiariey, J. 2009. Pengelolaan Antar Waktu Perikanan Pelagis Kecil di Provinsi Maluku Berdasarkan Kapsitas Penangkapan Ikan (Ringkasan Disertasi). Institut Pertanian Bogor. Bogor.

Hiariey. J dan St. M. Siahainenia. 1997. Kondisi Sosial Ekonomi Nelayan Bagan di Kabupaten Maluku Tengah. Laporan Penelitian Kerjasama Dengan Agricultural Research Management Project II (ARMP II).

Kirkley, J. E et al,. 2004. Deterministic and Stochastic Capacity Estimation For Fishery Capacity Reduction. Ichthyos, Vol. 8 No. 2, Juli 2009:

Lipsey dan Steiner. 1985. Pengantar Ilmu Ekonomi. Edisi Keenam. Penerbit PT. Bima Aksara. Jakarta.

Nicholson. W. 1991. Teori Ekonomi Mikro. Edisi Revisi. Penerbit Rajawali Press. Jakarta.

Nurkahim. S; V. P. H. Nikijuluw; D. Nugroho; B. I. Prisanto. 2007. Statuts Perikanan Menurut Wilayah Pengelolaan. Informasi Dasar Pemanfaatan Berkelanjutan. Pusat Riset Perikanan Tangkap, BRKP, Departemen Kelautan dan Perikanan.

Rangkuti. F. 2008. Analisis SWOT Teknik Membeda Kasus Bisnis Reorientasi Konsep Perencanaan Strategi Utama Menghadapi Abad - 21. PT. Gramedia Pustaka Utama. Jakarta.
Singgaribun. M dan Effendi. M. 2008. Metode Penelitian Survei (Ed Revisi). Lembaga Penelitian Pendidikan dan Penerangan Ekonomi dan Sosial (LP3ES). Jakarta. 


\section{PEDOMAN PENULISAN}

\section{Pedoman Umum}

a. PAPALELE, Jurnal Penelitian Ilmu Sosial Ekonomi Perikanan dan Kelautan memuat hasil penelitian yang berkaitan dengan bidang sosial ekonomi perikanan dan kelautan.

b. Naskah yang dikirim merupakan karya asli dan belum pernah diterbitkan atau dipublikasikan.

c. Naskah diketik dalam bahasa Indonesia yang baik dan benar, tidak diperkenankan menggunakan singkatan yang tidak umum.

d. Naskah diketik pada kertas A4 dengan menggunakan program microsoft word dengan 2 spasi, margin 2.5 $\mathrm{cm}$ (kiri), $2 \mathrm{~cm}$ (atas), $2 \mathrm{~cm}$ (bawah) dan 1,5 cm (kanan), font 12 times new roman, setiap halaman diberi nomor secara berurutan dengan berkolom 1 (satu), dikirim beserta soft copy maksimal 15 halaman.

e. Naskah dikirim melalui alamat ke redaksi pelaksana PAPALELE, Jurnal Penelitian Ilmu Sosial Ekonomi Perikanan dan Kelautan, Program Studi Sosial Ekonomi Perikanan Jurusan Teknologi Hasil Perikanan, Fakultas Perikanan dan Ilmu Kelautan, Universitas Pattimura, Jln. Mr. Chr. Soplanit Poka-Ambon Telp. (0911) 379859, email: inseijurnal@gmail.com.

\section{Pedoman Penulisan Naskah}

a. Judul tidak lebih dari 15 kata dalam bahasa Indonesia dan bahasa Inggris.

b. Nama lengkap penulis tanpa gelar, penulis korespondensi disertai dengan alamat email.

c. Nama lembaga/institusi disertai alamat lengkap dengan kode pos.

d. Abstrak dalam bahasa Indonesia dan bahasa Inggris tidak lebih dari 200 kata.

e. Kata kunci dalam bahasa Inggris dan Indonesia maksimal 5 kata kunci ditulis dibawah abstrak

f. Pendahuluan, memuat latar belakang, perumusan masalah, keragka teoritis dan tujuan penelitian yang dibuat secara ringkas.

g. Metodologi, memuat lokasi dan waktu penelitian, bagaimana data diperoleh dan sumbernya, bagaimana metode analisis data, jika metode yang digunakan telah diketahui sebelumnya harus dicantumkan acuannya.

h. Hasil dan Pembahasan, memuat suatu topik atau permasalahan yang terkait dengan judul, didukung dengan tabel dan gambar yang dibahas secara komperhensif, dikomplementasikan dengan referensi primer yang mendukung, update dan advance.

i. Kesimpulan dan Saran, memuat pokok-pokok bahasan serta kemampuan mengartikulasi temuan pokok untuk saran yang diberikan.

j. Ucapan terima kasih (bila diperlukan).

k. Daftar Pustaka, dicantumkan dalam naskah bila ada pengutipan dari sumber lain. Proporsi daftar pustaka yang diacu yaitu $80 \%$ merupakan rujukan primer dan $80 \%$ merupakan terbitan 10 tahun terakhir. Disusun berdasarkan abjad, dan penulisan sesuai dengan peraturan yang sudah baku, misalnya:

[KKP] Kementerian Kelautan dan Perikanan. 2012. Statistik Perikanan Tangkap 2011. Direktorat Jenderal Perikanan Tangkap Kementerian Kelautan dan Perikanan

Bataglia P, Romeo T, Consoli P, Scottie G, and Andoloro F. 2010. Characterization of The Artisanal Fishery and Its Socio-Economic aspect in The Central Menditerranean Sea (Aeolian Islands, Italy). Fisheries Research $102: 87-9$.

Pingkan W, Hamzens S, dan Sumardjo. 2007. Strategi Inovasi Sosial Pengembangan Mutu Sumberdaya Manusia Nelayan. Jurnal Penyuluhan Volume 3 Nomor 1.

Fauzi A. dan Anna S. 2005. Pemodelan Sumberdaya Perikanan dan Kelautan. Untuk Analisis Kebijakan. PT. Gramedia Pustaka Utama. Jakarta.

Wibawa T. J, Novianto D, dan Nugroho B. 2012. Sebaran Spasial Kelimpahan Ikan Cakalang (Katsuwonus Pelamis) Berdasarkan Analisis Data Satelit Oseanografi. Prosiding InSINas, 29-30 Nopember 2012.

Muksin D. 2006. Optimalisasi Usaha Perikanan Cakalang (Katsuwonus pelamis) Di Kota Tidore Kepulauan Provinsi Maluku Utara. Tesis. Program Pascasarjana IPB. Bogor.

Syandri H. 2013. Nelayan Cerdas, Nelayan Mandiri. http://www.bunghatta.ac.id/ (diunduh pada 12 September 2013).

1. Tabel, diketik dalam bahasa Indonesia, diberi judul pada bagian atas tabel, diberi nomor urut (tidak dalam bentuk JPEG).

m. Gambar dan grafik, diketik dalam bahasa Indonesia, diberi judul singkat pada bagian gawah gambar dan diberi nomor urut. 
PROGRAM STUDI AGRIBISNIS PERIKANAN

FAKULTAS PERIKANAN DAN ILMU KELAUTAN

UNIVERSITAS PATTIMURA

Jln. Mr. Chr. Soplanit, Poka - Ambon, Maluku Telepon : (0911) 379859

E-mail : inseijurnal@gmail.com

Web : http://ojs.unpatti.ac.id./index.php/insei

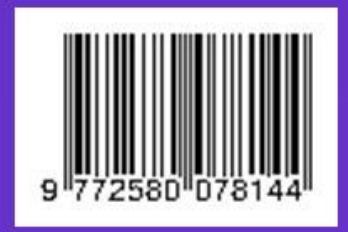

